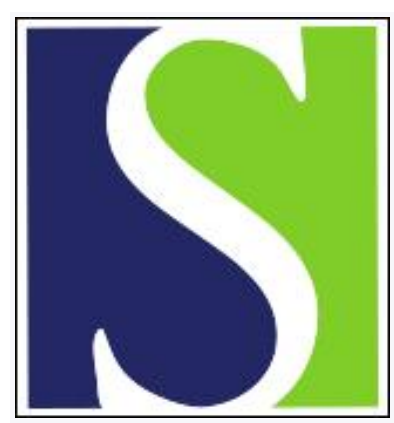

Scand J Work Environ Health 1985;11(1):15-19

https://doi.org/10.5271/sjweh.2259

Issue date: Feb 1985

Blood pressure and other cardiovascular risk factors of long-term exposure to lead.

by Kirkby $\mathrm{H}$, Gyntelberg $\mathrm{F}$

This article in PubMed: www.ncbi.nlm.nih.gov/pubmed/3992216

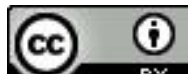




\title{
Blood pressure and other cardiovascular risk factors of long-term exposure to lead
}

\author{
by Hanne Kirkby, $M D^{1}$, Finn Gyntelberg, $M D^{2}$
}

\begin{abstract}
KIRKBY H, GYNTELBERG F. Blood pressure and other cardiovascular risk factors of long-term exposure to lead. Scand J Work Environ Health 11 (1985) 15-19. The coronary risk profile was studied for 96 heavily exposed lead smelter workers employed between 9 and 45 years and for a reference group not exposed to lead but comparable with respect to age, sex, height, weight, social grouping, occupational status, and alcohol and tobacco consumption. The lead smelter workers had a little higher diastolic blood pressure and significantly more ischemic electrocardiographic changes, and their high-density lipoprotein levels were lower than the corresponding values of the reference group. The lead workers with electrocardiographic changes had higher blood pressures than the referents with corresponding changes. These findings indicate a higher coronary risk profile for the examined lead smelter workers. The study supports the hypothesis of a positive association between lead exposure and arteriosclerosis and high blood pressure.
\end{abstract}

Key terms: arteriosclerosis, blood lipids, coronary risk profile, cross-sectional study, lead exposure.

Acute lead poisoning causes vasoconstriction leading to pallor of the skin with a slight reversible increase in blood pressure (14). Whether long-term lead exposure causes permanent hypertension is still being debated. In a study on workers' response to lead during a long period, Cramer \& Dahlberg (3) did not find a raised prevalence of hypertension, while Beevers et al (2), in a case-referent study, observed a significant excess of cases with high blood lead levels among male hypertensives compared with normotensives.

During the last 15 years cardiovascular disease epidemiology has been studied in several surveys at the Glostrup Population Study Unit. The facilities used in these investigations gave us an opportunity to study cardiovascular risk factors in workers exposed to lead on the long-term. In two previous papers we have described these workers' subjective symptoms and studied whether they had peripheral nerve disease $(6,7)$.

\section{Materials and methods}

\section{Exposed group}

All employees in a large lead smelting factory who had been employed for more than nine years were chosen for the study. Arbitrarily we chose a period of 10 years as criterion for "long-term" lead exposure at first, but, since this procedure gave a loss of sev-

1 The Glostrup Population Studies, Section of Prospective Medicine C, Glostrup Hospital, Faculty of Medicine, University of Copenhagen, Denmark.

2 Clinic of Occupational Medicine, Rigshospitalet, Copenhagen, Denmark.

Reprint requests to: Dr H Kirkby, Skovbakken 23, DK-3520 Farum, Denmark. eral employees, we decided to use a nine-year period. At the time of this study 265 were employed and among them 110 had been employed for more than nine years. Of them 92 men and 4 women $(88.9 \%$ ) agreed to participate in the study. Nonresponse was due to 2 subjects having moved abroad and 12 subjects refusing to participate for various reasons, to our knowledge the reasons being unrelated to their state of health.

\section{Reference group}

As a reference group 92 men and 3 women were chosen from a health survey study of 1000 residents aged $30-60$ years (1). This study was carried out one year earlier at the Glostrup Population Study Unit and used exactly the same methods as were used in the actual study. The matching of referents with the exposed group was attempted with respect to age, occupational status, and duration of employment. The matching procedure could not be carried out completely. Thus the reference group had been employed on an average of a few years less than the leadexposed group. Otherwise the matching was nearly complete.

\section{Exposure}

The lead exposure in the lead smelting factory has decreased during the last 20 years. Although it has been fairly difficult to get exact figures of air lead concentrations a decade ago, the hygienic standard of $0.2 \mathrm{mg} / \mathrm{m}^{3}$ has no doubt been exceeded in many places in the factory. Information on this point has been obtained from the local labor inspection office. Within the last five years, during which biological monitoring of blood lead levels has taken place, air levels have only occasionally exceeded the standard 
of $0.1 \mathrm{mg} / \mathrm{m}^{3}$. The exposure is however rather different in various places. During certain work procedures the dust levels in the air may exceed the hygienic standard many times, and during such work the workers wear a dust mask. All the examined workers have worked in different areas at one time or another, and it is fairly impossible to get exact estimates of lead exposure for any single individual. The kind of work carried out in the plant, including production of nonferrous metals and alloys by recovery and further refinment from spent lead-containing batteries and other lead residues, involves no doubt high lead exposure.

Since 1976 the blood lead level of all the employees has been monitored every third month. If it exceeds $60 \mu \mathrm{g} / 100 \mathrm{ml}(2.9 \mu \mathrm{mol} / \mathrm{l})$, a new measurement is made. If the second measurement is between $60-80$ $\mu \mathrm{g} / 100 \mathrm{ml}(2.9-3.9 \mu \mathrm{mol} / \mathrm{l})$, the employee is transferred to another, less exposed position in the factory. If it exceeds $80 \mu \mathrm{g} / 100 \mathrm{ml}(3.9 \mu \mathrm{mol} / \mathrm{l})$, the employee is sent to the local occupational health clinic.

\section{Examination procedure}

The participants received a comprehensive questionnaire including questions on subjective symptoms, chest pain, alcohol and tobacco consumption, physi- cal activity at work and during leisure time, dietary habits, cardiovascular diseases among relatives, own health appraisal, and social relations. The questionnaires were self-administered and were followed by an interview by one of us, who checked the answers to the questionnaires. The standardized questions, according to the World Health Organization (WHO) (10), were translated into Danish and used to estimate the prevalence of angina pectoris, possible infarction, and intermittent claudication.

All participants came to the clinic in the morning after fasting and nonsmoking for $12 \mathrm{~h}$. After the questionnaire was checked, a venous blood sample was drawn from the subject in the supine position; the sample was used in the determination of the blood levels of hemoglobin, hematocrit, reticulocytes, serum asparate aminotransferase, alkaline phosphatase, creatinine, and glucose, all of which were determined by the routine methods of our hospital laboratory. Venous blood samples for the determination of serum cholesterol, triglycerides, and high-density lipoprotein cholesterol were handled by the lipid laboratory of the Department of Internal Medicine C, using methods previously described (11). Since 1978 The Glostrup Study has participated in the Cholesterol and Triglyceride Standardization Programme, organized by WHO, and the coefficient

Table 1. Means [and standard deviations (SD) and confidence limits (95\%) where appropriate] of the blood lead levels, the zinc protoporphyrin, and various life-style factors of the lead workers and the referents.

\begin{tabular}{|c|c|c|c|c|c|c|}
\hline & \multicolumn{3}{|c|}{ Lead workers } & \multicolumn{3}{|c|}{ Referents } \\
\hline & Mean & SD & $\begin{array}{l}95 \% \text { confidence } \\
\text { limits }\end{array}$ & Mean & SD & $\begin{array}{l}95 \% \text { confidence } \\
\text { limits }\end{array}$ \\
\hline Blood lead $(\mu \mathrm{g} / 100 \mathrm{ml})^{\mathrm{a}}$ & 51 & 16 & . & 11 & 3 & . \\
\hline Zinc protoporphyrin $(\mu \mathrm{mol} / \mathrm{mol} \mathrm{Hb})$ & 317 & 235 & . & 68 & 7 & . \\
\hline \multicolumn{7}{|l|}{ Alcohol consumption } \\
\hline $\begin{array}{l}\text { Beer (bottles/week) } \\
\text { Wine (glasses/week) }\end{array}$ & $\begin{array}{l}8.3 \\
1.4\end{array}$ & $\begin{array}{l}8.0 \\
2.4\end{array}$ & . & $\begin{array}{r}10.7 \\
1.3\end{array}$ & $\begin{array}{r}11.7 \\
2.3\end{array}$ & $\dot{.}$ \\
\hline \multicolumn{7}{|l|}{ Smoking habits } \\
\hline $\begin{array}{l}\text { Percentage of group who smoke } \\
\text { Cigarettes/d } \\
\text { Cheroots/d } \\
\text { Cigars/d } \\
\text { Pipe (g/week) } \\
\text { Years of smoking }\end{array}$ & $\begin{array}{r}59.4 \\
11.3 \\
0.6 \\
0.2 \\
23.5 \\
29.9\end{array}$ & $\begin{array}{r}8.6 \\
1.9 \\
0.7 \\
55.3 \\
12.9\end{array}$ & $\begin{array}{c}48.9-69.3 \\
: \\
: \\
:\end{array}$ & $\begin{array}{r}63.5 \\
9.0 \\
2.1 \\
0.2 \\
30.4 \\
29.3\end{array}$ & $\begin{array}{r}9.1 \\
3.7 \\
1.2 \\
54.0 \\
12.3\end{array}$ & $\begin{array}{c}53.0-73.1 \\
: \\
: \\
: \\
:\end{array}$ \\
\hline \multicolumn{7}{|l|}{ Physical activity } \\
\hline $\begin{array}{l}\text { Bicycling (min/d) } \\
\text { Percentage of group who jog } \\
\text { Percentage of group who }\end{array}$ & $\begin{array}{l}17 \\
12.8\end{array}$ & 21 & $4.3-27.4$ & $\begin{array}{l}11 \\
24.0\end{array}$ & 25 & $9.4-45$ \\
\hline $\begin{array}{l}\text { participate in sport } \\
\text { Time spent participating in sport }\end{array}$ & 18.9 & . & $11.6-28.3$ & 23.9 & . & $15.8-33.8$ \\
\hline $\begin{array}{l}\text { (h/week) } \\
\text { Percentage of leisure-time activity }\end{array}$ & 0.6 & 1.0 & . & 2.6 & 2.5 & . \\
\hline $\begin{array}{l}\text { Sitting } \\
\text { Light activity } \\
\text { Moderate activity }\end{array}$ & $\begin{array}{l}35.4 \\
51.0 \\
13.5\end{array}$ & $\dot{.}$ & $\begin{array}{r}26.9-46.9 \\
40.6-61.4 \\
7.4-22.0\end{array}$ & $\begin{array}{l}35.1 \\
47.9 \\
17.0\end{array}$ & $\dot{.}$ & $\begin{array}{l}25.5-45.6 \\
37.5-58.4 \\
10.1-26.2\end{array}$ \\
\hline $\begin{array}{l}\text { Moderate activity } \\
\text { Percentage of physical activity } \\
\text { at work }\end{array}$ & 13.5 & . & $7.4-22.0$ & 17.0 & . & $10.1-26.2$ \\
\hline $\begin{array}{l}\text { Sitting } \\
\text { Light work } \\
\text { Moderate work } \\
\text { Hard work }\end{array}$ & $\begin{array}{r}12.6 \\
56.3 \\
23.0 \\
8.1\end{array}$ & $\dot{.}$ & $\begin{array}{r}6.5-21.5 \\
45.3-66.9 \\
14.6-33.3 \\
3.3-15.9\end{array}$ & $\begin{array}{l}16.0 \\
44.7 \\
26.6 \\
12.8\end{array}$ & . & $\begin{array}{r}9.2-25.0 \\
34.4-55.3 \\
18.0-36.7 \\
6.8-21.2\end{array}$ \\
\hline
\end{tabular}

a $1 \mu \mathrm{g} / 100 \mathrm{ml}=0.048 \mu \mathrm{mol} / \mathrm{l}$. 
Table 2. Body weight, blood pressure, and lipid values of the lead workers and the referents. (NS = not significant)

\begin{tabular}{|c|c|c|c|c|c|}
\hline & \multicolumn{2}{|c|}{ Lead employees } & \multicolumn{2}{|c|}{ Referents } & \multirow{2}{*}{$\begin{array}{l}\text { Level of } \\
\text { signifi- } \\
\text { cance }\end{array}$} \\
\hline & Mean & SD & Mean & $S D$ & \\
\hline Body weight (kg) & 78.6 & 11.9 & 76.0 & 11.2 & NS \\
\hline \multicolumn{6}{|l|}{ Blood pressure $(\mathrm{mm} \mathrm{Hg})^{a}$} \\
\hline \multicolumn{6}{|l|}{ Sitting position } \\
\hline $\begin{array}{l}\text { Systolic } \\
\text { Diastolic }\end{array}$ & $\begin{array}{r}135 \\
86\end{array}$ & $\begin{array}{l}21 \\
12\end{array}$ & $\begin{array}{r}133 \\
82\end{array}$ & $\begin{array}{l}20 \\
11\end{array}$ & $\begin{array}{l}\text { NS } \\
0.04\end{array}$ \\
\hline \multicolumn{6}{|l|}{ Supine position } \\
\hline Systolic & 135 & 18 & 129 & 18 & NS \\
\hline Diastolic & 83 & 12 & 78 & 12 & 0.005 \\
\hline \multicolumn{6}{|l|}{ Ultrasound systolic pressure } \\
\hline Right arm & 135 & 18 & 133 & 17 & NS \\
\hline Left arm & 144 & 19 & 135 & 19 & 0.03 \\
\hline Right dorsal artery of foot & 165 & 28 & 154 & 22 & 0.05 \\
\hline Left dorsal artery of foot & 164 & 27 & 155 & 23 & 0.03 \\
\hline \multicolumn{6}{|l|}{ Lipids } \\
\hline \multirow{3}{*}{$\begin{array}{l}\text { Total cholesterol }(\mathrm{mg} \%) \\
\text { Triglycerides (mmol//) } \\
\text { High-density lipoprotein cholesterol } \\
\text { (mg\%) }\end{array}$} & 247.1 & 50.1 & 257.1 & 51.6 & NS \\
\hline & 1.24 & 0.87 & 1.33 & 1.33 & NS \\
\hline & 50.5 & 9.5 & 54.9 & 11.6 & 0.004 \\
\hline
\end{tabular}

a $1 \mathrm{~mm} \mathrm{Hg} \approx 0.133 \mathrm{kPa}$.

of variation has been found to be within recommended limits. Venous blood samples for blood lead level determination were taken, and blood lead was determined by atomic absorption spectrophotometry. The quality of the method has been carefully evaluated and compared with international standards (8). Erythrocyte zinc protoporphyrin was measured with a hematofluorometer (5).

The participants were weighed and had their height measured. Resting electrocardiograms with nine leads (I, II, III, V 1-6) were recorded and coded according to the Minnesota Code by a trained expert (10). Blood pressure was taken both with the subject in the supine position, with a random zero spygmomanometer, and in the sitting position, with a usual mercury spygmomanometer. All the measurements made in the supine position were performed by the same trained nurse, and the measurements in the sitting position were taken by one us. As a definition of hypertension a blood pressure of $\geq 160 / 95$ $\mathrm{mmHg}$ ( $\geq 21.3 / 12.6 \mathrm{kPa}$ ) was used.

Systolic ankle and arm blood pressure was measured with the Doppler ultrasound technique (12).

\section{Statistical methods}

Statistical differences between the lead-exposed and reference groups were estimated by use of the MannWhitney and the chi-square test. The level of significance was set at $5 \%$. Correlations were evaluated with a Spearman rank test.

\section{Results}

\section{Life-style coronary risk factors}

In table 1 answers to the questionnaire on alcohol consumption, smoking habits, and physical activity at work and during leisure time are shown. No im-
Table 3. Prevalence of angina pectoris, intermittent claudication, and ischemic electrocardiographic changes in lead workers and referents.

\begin{tabular}{lccc}
\hline & $\begin{array}{c}\text { Lead } \\
\text { workers } \\
(\%)\end{array}$ & $\begin{array}{c}\text { Referents } \\
(\%)\end{array}$ & $\begin{array}{c}\text { Level of } \\
\text { signifi- } \\
\text { cance }\end{array}$ \\
\cline { 2 - 4 } & 4 & 2 & NS \\
$\begin{array}{l}\text { Angina pectoris } \\
\text { Intermittent claudication }\end{array}$ & 0 & 0 & $\cdot$ \\
$\begin{array}{l}\text { Ischemic electro- } \\
\text { cardiographic changes }\end{array}$ & 20 & 6 & $<0.01$ \\
\hline
\end{tabular}

portant statistically significant differences were observed with regard to these life-style factors. The mean values of the blood lead concentrations and zinc protoporphyrin also appear in table 1 .

The mean duration of the actual employment of the lead workers was 22 years, and that of the reference group was 19 years $(p<0.05)$. Among the lead employees $32 \%$ were functionals, $12 \%$ were skilled, and $56 \%$ unskilled workers; in the reference group $39 \%$ were functionals, $20 \%$ were skilled, and $38 \%$ unskilled workers.

\section{Endogenous cardiovascular risk factors}

In table 2 the results obtained for the endogenous cardiovascular risk factors body weight, blood pressure, and serum lipids are given. No statistically significant differences were observed, with regard to systolic blood pressure, but the lead workers had higher diastolic blood pressure values in both the supine and sitting positions, $4(\mathrm{p}<0.04)$ and 5 $(\mathrm{p}<0.05) \mathrm{mmHg}$, respectively $(0.53$ and $0.67 \mathrm{kPa}$, respectively). Systolic blood pressure, as measured by the ultrasound device, showed higher systolic blood pressures in the left arm and in the arteries of the feet. 
Table 4. Blood pressure measurements from the lead workers and referents with ischemic electrocardiographic (ECG) changes.

\begin{tabular}{lccccc}
\hline & \multicolumn{2}{c}{$\begin{array}{c}\text { Lead workers with } \\
\text { ECG ischemic } \\
\text { changes }\end{array}$} & & \multicolumn{2}{c}{$\begin{array}{c}\text { Referents with } \\
\text { ECG ischemic } \\
\text { changes }\end{array}$} \\
\cline { 2 - 3 } & Mean & SD & & Mean & SD \\
Level of \\
significance
\end{tabular}

a $1 \mathrm{~mm} \mathrm{Hg} \approx 0.133 \mathrm{kPa}$.

No statistically significant differences were observed with regard to body weight. No statistically significant differences in total serum cholesterol and serum triglycerides were observed, but high-density lipoprotein cholesterol was statistically significantly lower in the lead employees $(p<0.004)$.

\section{Prevalence of angina pectoris, intermittent claudication and electrocardiographic changes according to the Minnesota Code}

In table 3 the results obtained on angina pectoris, intermittent claudication, and electrocardiographic changes are shown. No statistically significant differences were observed between the exposed subjects and the referents with respect to the prevalence of angina pectoris and intermittent claudication, but more lead smelter workers had ischemic changes in their electrocardiograms than the referents $(\mathrm{p}<$ 0.01), as defined according to the London Whitehall study (9). As seen in table 4, the lead smelter workers with electrocardiographic changes had significantly higher blood pressures.

A correlation analysis between the blood pressure values and the zinc protoporphyrin levels and the blood lead levels was carried out. No statistically significant correlations were observed.

\section{Discussion}

In this study lead workers employed long-term were found to have a higher coronary risk profile than a comparable reference group. Thus the lead workers had a slightly higher diastolic blood pressure, more ischemic electrocardiographic changes, and lower high-density lipoprotein cholesterol values than the referents. These findings may indicate a higher risk to incur major cardiovascular diseases such as myocardial infarction and stroke. Therefore these findings support the results reported by Dingwall-Fordyce \& Lane (4), who found a significant excess of deaths from cerebrovascular disease among lead workers (who assumedly had been heavily exposed to lead at the beginning of this century). For lead workers employed later, the risk of dying from cerebrovascular disease was not elevated. In addition a recent autopsy study showed a positive correlation between aorta lead levels and the degree of arteriosclerosis (13).

The lack of correlation between blood pressure values and zinc protoporphyrin levels and blood lead levels does not indicate a causal relationship between high blood lead levels and high blood pressure. However, neither did the other parameters with known association to high blood pressure (body weight, alcohol consumption, tobacco smoking, age, and social class differences) explain the differences observed. The lower high-density lipoprotein cholesterol levels could not be explained by the confounding factors measured. The electrocardiographic changes, however, might be due to the higher blood pressure values found for the lead workers. The lead smelter workers may be exposed to other factors in the work environment, ie, low levels of antimony, general air pollution (smoke and dust), and isometric exercise (from lifting burdens). Such factors may contribute to the higher coronary risk profile found for the lead workers.

The findings of the present study indicate that lead smelter workers may have a higher risk of coronary heart disease and major cardiovascular diseases, a hypothesis that should be tested in retro- or prospective cohort studies, and a search should be started for etiologic factors in the lead smelters' work environment.

\section{References}

1. Agner E, Brendstrup T, Hollnagel H, Mørck HI, Schroll M, Gyntelberg F. Interventionsundersøgelsen i Glostrup 1978. Ugeskr Laeg 141 (1979) 3543-3548.

2. Beevers DG, Erskine E, Robertson M, Beattie AD, Campbell BC, Goldberg A, Hawthorne VM. Bloodlead and hypertension. Lancet 2 (1976) 1-3.

3. Cramer K, Dahlberg L. Incidence of hypertension among lead workers. Br J Ind Med 23 (1966) 101-104.

4. Dingwall-Fordyce I, Lane RE. A follow-up of lead workers. Br J Ind Med 20 (1963) 313-315. 
5. Grandjean P. Occupational lead exposure in Denmark: Screening with the haematofluorometer. $\mathrm{Br} \mathbf{J}$ Ind Med 36 (1979) 52-58.

6. Kirkby H, Nielsen CJ, Nielsen VK, Gyntelberg F. Subjective symptoms after long term lead exposure in secondary lead smelting workers. Br J Ind Med 40 (1983) $314-317$

7. Nielsen CJ, Nielsen VK, Kirkby H, Gyntelberg F. Absence of peripheral neuropathy in longterm lead exposed subjects. Acta Neurol Scand 65 (1982) 241-247.

8. Olsen NB, Hollnagel H, Grandjean P.. Indicators of lead exposure in an adult Danish suburban population. Dan Med Bull 28 (1981) 168-176.

9. Reid DD, Hamilton PJS, Keen H, Brett GZ, Jarett RJ, Rose G. Cardiorespiratory disease and diabetes among middle-aged male civil servants. Lancet 1 (1974) 469473.

10. Rose GA, Blackburne H. Cardiovascular survey methods. World Health Organization, Geneva 1968.
11. Schroll M, Grunnet K, Hansen PF. Fasting serum cholesterol and triglyceride values in a ten years prospective study of the 1914-population in Glostrup, 1964-1974. Dan Med Bull 28 (1981) 251-259.

12. Schroll M, Munck O. Estimation of peripheral arteriosclerotic disease by ankle blood pressure measurements in a population study of 60 -year old men and women. J Chronic Dis 34 (1981) 261-269.

13. Voors AW, Johnson WD. Additive statistical effects of cadimum and lead on heart-related disease in a North Carolina autopsy series. Arch Environ Health 37 (1982) 98-102.

14. Zielhuis RL. Lead alloys and compounds. In: International Labor Office. Occupational Health and Safety. Geneva 1976, pp 767-772.

Received for publication: 21 November 1983 